\title{
Wpływ sposobu oczyszczania rdzeni i próbek okruchowych ze składników płuczki olejowej na parametry geochemiczne Rock Eval
}

\begin{abstract}
W pracy przetestowano skuteczność różnych mieszanin i rozpuszczalników w oczyszczaniu próbek okruchowych i rdzeniowych zanieczyszczonych składnikami płuczki olejowej. Przeprowadzone testy wykazały, że w żadnym przypadku nie uzyskano w $100 \%$ satysfakcjonującego efektu w postaci selektywnego wymycia niepożądanych zanieczyszczeń. Pomimo braku wyboru jednego środka czyszczącego udało się zminimalizować efekt zanieczyszczenia w drodze płukania alkoholem izopropylowym. W pracy przeanalizowano także i oszacowano zakres wpływu składników płuczki olejowej na uzyskiwane parametry geochemiczne z badań Rock Eval próbek okruchowych oraz rdzeniowych, charakteryzujących się różną litologią i różnymi własnościami przepuszczalności i zasobności w substancję organiczną.
\end{abstract}

Słowa kluczowe: dodatki olejowe do płuczki wiertniczej, przygotowanie próbki, testy rozpuszczalnikowe, parametry geochemiczne.

\section{Influence of cores and cuttings cleaning from oil-based mud on geochemical Rock Eval parameters}

The studies tested the effectiveness of different mixtures and solvents in cleaning the cuttings and core samples contaminated by components of an oil based drill mud. The tests carried out showed that in no case was a $100 \%$ satisfactory result obtained, for selectively washed unwanted impurities. Despite the lack of choice of one single cleaning agent, we were able to minimize the effect of pollution by washing with isopropyl alcohol. The studies analyzed and assessed, the scope of the impact of the components of the oil mud on the geochemical parameters obtained from the Rock Eval analyses of cuttings and core samples, which are characterized by different lithology, permeability properties and are abundant in organic matter.

Key words: drilling oil mud additive, sample preparation, geochemical parameters, solvent testing.

\section{Wprowadzenie}

Stosowanie płuczek opartych na dodatkach olejowych, mimo że spełnia rolę w odniesieniu do poprawienia własności ścian otworu, to jednak sprawia ogromne trudności $\mathrm{w}$ interpretacji wyników badań prowadzonych w otworze wiertniczym $[2,7]$. Problem zanieczyszczeń pochodzących z płuczki jest także istotny w ocenie przypływu ropy naftowej podczas wiercenia. $\mathrm{W}$ badaniach prowadzonych w Laboratorium Geochemii Nafty i Gazu INiG - PIB stwierdzono znaczny wpływ płuczki olejowej na wyniki badań próbek rdzeniowych oraz okruchowych. Zachodzi zatem konieczność zdefiniowania skali problemu, aby móc zminima- lizować efekty widziane w wartościach parametrów geochemicznych. Jest to problem, z którym coraz częściej przychodzi nam się zmierzyć, jako że płuczka na bazie oleju syntetycznego jest obecnie powszechnie stosowana w pracach wiertniczych zarówno w poszukiwaniach złóż konwencjonalnych, jak i niekonwencjonalnych [1]. Usuwanie składników płuczki olejowej w taki sposób, aby jednocześnie zachować związki organiczne obecne w skale, jest zadaniem trudnym, gdyż olej będący składnikiem płuczki olejowej ma właściwości fizykochemiczne bardzo zbliżone do właściwości ropy naftowej oraz substancji bitumicznych rozproszonych 
w skałach. W szczególności olej, ropa i bituminy wykazują powinowactwo do tych samych rozpuszczalników, co praktycznie utrudnia całkowite selektywne usunięcie zanieczyszczenia olejowego pochodzącego z płuczki wiertniczej bez naruszenia węglowodorów obecnych w skale. Badania były prowadzone w celu opracowania takiej metody usuwania składników płuczki olejowej, aby jednocześnie zachować związki organiczne obecne w skale.

Prace zostały zaplanowane tak, aby badaniami objąć różne litologicznie próbki skał i wykonać dla nich analizy Rock Eval. Do testów wykorzystano płuczkę olejową stosowaną przez PGNiG S.A. Próbki użyte do testów pochodziły z otworów wierconych płuczką olejową i reprezentowały serie łupkowe z otworu horyzontalnego. Ponadto wykorzystano próbki z odsłonięć powierzchniowych, które kruszono do rozmiarów odpowiadających zwykle próbkom okruchowym i poddawano działaniu płuczki olejowej.

Wykonano kilkanaście oznaczeń pirolizy Rock Eval oraz ekstrakcji bituminów próbek oczyszczanych różnymi metodami i porównywano rezultaty z próbkami naturalnymi, niepoddawanymi żadnym zabiegom. Wyniki badań pozwoliły na oszacowanie ilościowego wpływu zanieczyszczeń olejowych na poszczególne parametry geochemiczne, a z drugiej strony na ocenę mieszanin stosowanych w procesie oczysz- czania próbek okruchowych i rdzeniowych zanieczyszczonych olejowymi składnikami płuczki. Od kilkunastu lat firmy serwisowe pracują nad zminimalizowaniem wpływu zanieczyszczonego materiału badawczego na efekt interpretacyjny $[5,6,7]$. Obecnie stosowane oleje to głównie oleje syntetyczne na bazie parafin, olefin lub estrów z różnorodnymi dodatkami organicznymi (glikole) i dodatkami nieorganicznymi. W związku z tym nieuniknione jest zanieczyszczenie próbek do badań geochemicznych. Stopień zanieczyszczenia zależy od litologii matrycy mineralnej skały, typu próbek (okruchowe, rdzeniowe, rdzenie boczne) i od warunków wiercenia. Zatem poznanie natury zanieczyszczenia i skala jego wpływu na poszczególne oznaczane parametry są istotne $\mathrm{w}$ dalszych badaniach $\mathrm{i}$ interpretacji geologicznej. Firma Geotech wykonała dwa raporty określające rodzaj zanieczyszczeń spowodowanych dodatkami w płuczce olejowej i wypracowała sposób interpretacji wyników obarczonych wpływem czynników zanieczyszczających badany materiał [3].

Raporty te są odpłatne i w razie dalszych badań należałoby po nie sięgnąć. W raportach tych zwrócono uwagę, że omawiany wpływ jest zauważalny nie tylko podczas oznaczeń TOC, ale także podczas badań ekstraktów i późniejszych analiz GC-MS frakcji nasyconej oraz frakcji aromatycznej.

\section{Dobór rozpuszczalników do wymywania składników płuczki olejowej}

Wymywanie składników płuczki olejowej w taki sposób, aby jednocześnie zachować związki organiczne obecne w skale, jest zadaniem trudnym. W pracy tej przetestowano kilka sposobów usuwania oleju: przemywano próbki ciepłą wodą z detergentem, oddziaływano na zanieczyszczone próbki okruchowe środkami powierzchniowo czynnymi - w postaci środka do usuwania zanieczyszczeń ropopochodnych o handlowej nazwie Sintan, działano na próbki rozpuszczalnikami organicznymi: alkoholem izopropylowym, mieszaniną toluen-n-heksan w stosunku objętościowym 3:1, mieszaniną dichlorometan-metanol w stosunku objętościowym 93:7, poddano próbki reakcji zmydlania (tablice 1 i 2 ). Eksperymenty wykonywano na próbkach według następującego schematu postępowania: próbki w ilości 5 gramów traktowano $30 \mathrm{ml}$ odczynnika czyszczącego i wytrząsano przez 2 godziny, po czym oddzielano od odczynnika czyszczącego, suszono na powietrzu, ucierano w moździerzu i analizowano w analizatorze Rock Eval. W przypadku próbek poddanych reakcji zmydlania mieszaninę stężonego roztworu wodorotlenku sodu z próbką podgrzewano do wrzenia, mieszając. Następnie pozostałość, po usunięciu roztworu, płukano kilkakrotnie ciepłą wodą, suszono na powietrzu i po utarciu w moździerzu wykonywano analizy Rock Eval. Z danych literaturowych wynika $[8,9,10]$, że mieszaniny środków powierzchniowo czynnych wykorzystywane są na wiertniach w instalacjach do usuwania węglowodorów ze zwiercin. Powierzchniowo czynne substancje, zwane także surfaktantami, to grupa związków chemicznych, których cząsteczki są zbudowane z 2 elementów o różnym powinowactwie do wody - z części hydrofobowej (o małym powinowactwie) oraz części hydrofilowej (o dużym powinowactwie).

Charakterystyczną cechą wszystkich substancji powierzchniowo czynnych jest zdolność do adsorbowania się na granicy faz. Tworząca się warstwa adsorpcyjna służy jako łącznik między fazami nierozpuszczalnymi (np. woda-olej), obniżając napięcie powierzchniowe na granicy faz, a tym samym ułatwiając ich rozdzielenie.

Do badania wpływu substancji powierzchniowo czynnych na zanieczyszczone płuczką olejową próbki okruchowe i rdzeniowe użyto preparatu o nazwie handlowej Sintan, stosowanego do usuwania zanieczyszczeń ropopochodnych z powierzchni ciał stałych. Z karty charakterystyki Sintanu wynika, że składa się on z mieszaniny niejonowych środków powierzchniowo czynnych - polimeru w ilości mniejszej niż 10\%, a także $\mathrm{z}$ anionowych środków powierzchniowo czynnych w ilości mniejszej niż 1\%. 
Tablica 1. Wyniki analizy pirolitycznej Rock Eval próbek okruchowych z odwiertu wertykalnego poddanych różnym procesom oczyszczania

\begin{tabular}{|c|c|c|c|c|c|c|c|c|c|c|c|c|c|}
\hline $\begin{array}{l}\frac{\pi}{0} \\
\frac{\pi}{0} \\
0\end{array}$ & $\begin{array}{c}\text { Stan próbki poddanej } \\
\text { zabiegom }\end{array}$ & $\begin{array}{c}\text { Sposób usuwania } \\
\text { składników płuczki } \\
\text { olejowej }\end{array}$ & $T_{\max }$ & $S_{1}$ & $S_{2}$ & $S_{3}$ & PI & $\mathrm{PC}$ & $\mathrm{RC}$ & TOC & HI & OI & MINC \\
\hline \multirow{4}{*}{1} & \multirow{16}{*}{$\begin{array}{l}\text { Próbka okruchowa } \\
\text { z odwiertu wierconego } \\
\text { płuczką olejową }\end{array}$} & płuczka olejowa & 440 & 3,06 & 4,76 & 1,37 & 0,39 & 0,69 & 0,52 & 1,21 & 393 & 113 & 3,53 \\
\hline & & Sintan & 437 & 1,06 & 5,43 & 0,30 & 0,16 & 0,56 & 0,31 & 0,87 & 624 & 34 & 6,18 \\
\hline & & proces zmydlania & 442 & 3,45 & 3,97 & 0,57 & 0,46 & 0,64 & 0,34 & 0,98 & 405 & 58 & 4,90 \\
\hline & & alkohol izopropylowy & 441 & 0,25 & 3,69 & 1,05 & 0,06 & 0,36 & 0,60 & 0,96 & 384 & 109 & 4,46 \\
\hline \multirow{4}{*}{2} & & płuczka olejowa & 420 & 6,23 & 15,44 & 0,42 & 0,29 & 1,83 & 2,32 & 4,15 & 372 & 10 & 0,22 \\
\hline & & Sintan & 418 & 2,45 & 19,21 & 0,06 & 0,11 & 1,81 & 2,06 & 3,87 & 496 & 2 & 0,51 \\
\hline & & proces zmydlania & 420 & 5,96 & 12,93 & 0,29 & 0,32 & 1,58 & 2,44 & 4,02 & 322 & 7 & 0,18 \\
\hline & & alkohol izopropylowy & 421 & 1,32 & 12,69 & 0,94 & 0,09 & 1,19 & 2,32 & 3,51 & 362 & 27 & 0,20 \\
\hline \multirow{4}{*}{3} & & płuczka olejowa & 437 & 8,66 & 3,99 & 0,27 & 0,68 & 1,07 & 1,28 & 2,35 & 170 & 11 & 1,52 \\
\hline & & Sintan & 356 & 1,10 & 5,71 & 0,16 & 0,16 & 0,57 & 0,68 & 1,25 & 457 & 13 & 3,67 \\
\hline & & proces zmydlania & 437 & 3,46 & 2,84 & 0,37 & 0,55 & 0,54 & 0,68 & 1,22 & 233 & 30 & 2,61 \\
\hline & & alkohol izopropylowy & 435 & 0,81 & 3,85 & 2,41 & 0,17 & 0,46 & 1,15 & 1,61 & 239 & 150 & 2,01 \\
\hline \multirow{4}{*}{4} & & płuczka olejowa & 440 & 9,79 & 13,83 & 0,89 & 0,41 & 1,99 & 0,75 & 2,74 & 505 & 32 & 0,63 \\
\hline & & Sintan & 445 & 3,41 & 12,18 & 0,49 & 0,22 & 1,32 & 0,77 & 2,09 & 583 & 23 & 1,02 \\
\hline & & proces zmydlania & 441 & 11,3 & 11,35 & 0,36 & 0,50 & 1,90 & 0,76 & 2,66 & 427 & 14 & 1,29 \\
\hline & & alkohol izopropylowy & 442 & 1,17 & 8,91 & 1,46 & 0,12 & 0,88 & 0,73 & 1,61 & 553 & 91 & 1,25 \\
\hline
\end{tabular}

$T_{\max }$ - temperatura, przy której podczas krakingu kerogenu powstaje maksymalna ilość węglowodorów [ $\left.{ }^{\circ} \mathrm{C}\right] ; S_{1}-$ zawartość wolnych węglowodorów [mg HC/g skały]; $S_{2}$ - ilość węglowodorów uwalnianych podczas krakingu kerogenu [mg HC/g skały]; $S_{3}-$ ilość $\mathrm{CO}_{2}$ powstałego podczas pirolizy kerogenu [mg CO $2 / g$ skały]; PI $=S_{1} /\left(S_{1}+S_{2}\right)$ - wskaźnik generowania; PC - zawartość węgla pirolitycznego [\% wag.]; RC - zawartość węgla rezydualnego [\% wag.]; TOC - całkowita zawartość węgla organicznego [\% wag.]; HI - wskaźnik wodorowy [mg HC/g TOC]; OI - wskaźnik tlenowy $\left[\mathrm{mg} \mathrm{CO}_{2} / \mathrm{g} \mathrm{TOC}\right] ;$ MINC - całkowita zawartość węgla mineralnego [\% wag.].

Istotną cechą tego preparatu jest jego biodegradowalność na poziomie $97 \div 99,7 \%$ [4].

Aby zobrazować skalę trudności w interpretowaniu rezultatów czyszczenia, dla trzech próbek wierconych płuczką olejową przeprowadzono ekstrakcję bituminów. Przed ekstrakcją próbki poddano procesowi czyszczenia mieszaniną toluenu z n-heksanem (3:1). Wyniki badań Rock Eval (tablica 2) wskazywały na właściwie dobraną mieszaninę czyszczącą, gdyż nastąpiło znaczne obniżenie wartości $S_{1}$ w stosunku do próbki zanieczyszczonej olejem, ale duża ilość ekstrahowalnej substancji organicznej wskazywała na niecałkowite usunięcie płuczki olejowej z próbek (tablica 3, rysunek 2).

Niskie wartości frakcji węglowodorów nasyconych sugerują możliwość wymycia większej części węglowodorów podczas usuwania składników płuczki olejowej poprzez zastosowanie jako czynnika wymywającego mieszaniny toluen-n-heksan. Wykonano ponownie ekstrakcję i rozdział grupowy dla tych samych próbek, ale tym razem przygotowanych

Tablica. 2. Wyniki analizy pirolitycznej Rock Eval próbek okruchowych wierconych płuczką olejową

\begin{tabular}{|c|c|c|c|c|c|c|c|c|c|c|c|c|}
\hline $\begin{array}{l}\mathrm{Nr} \\
\text { próbki }\end{array}$ & $\begin{array}{c}\text { Stan próbki poddanej za- } \\
\text { biegom }\end{array}$ & $T_{\max }$ & $S_{1}$ & $S_{2}$ & $S_{3}$ & PI & $\mathrm{PC}$ & $\mathrm{RC}$ & TOC & $\mathrm{HI}$ & OI & MINC \\
\hline \multirow[b]{2}{*}{1} & próbka nieczyszczona & 433 & 14,12 & 4,43 & 0,52 & 0,76 & 1,57 & 3,59 & 5,16 & 86 & 10 & 0,93 \\
\hline & $\begin{array}{l}\text { próbka czyszczona mie- } \\
\text { szaniną toluen-heksan } 3: 1\end{array}$ & 439 & 3,65 & 3,89 & 0,20 & 0,48 & 0,64 & 3,87 & 4,51 & 86 & 4 & 1,13 \\
\hline \multirow[b]{2}{*}{2} & próbka nieczyszczona & 435 & 19,06 & 5,33 & 0,38 & 0,78 & 2,05 & 4,66 & 6,71 & 79 & 6 & 0,30 \\
\hline & $\begin{array}{l}\text { próbka czyszczona mie- } \\
\text { szaniną toluen-heksan 3:1 }\end{array}$ & 442 & 5,03 & 3,90 & 0,20 & 0,56 & 0,76 & 4,56 & 5,32 & 73 & 4 & 0,29 \\
\hline \multirow[b]{2}{*}{3} & próbka nieczyszczona & 429 & 10,31 & 5,24 & 0,76 & 0,66 & 1,33 & 0,57 & 1,90 & 276 & 40 & 0,39 \\
\hline & $\begin{array}{l}\text { próbka czyszczona mie- } \\
\text { szaniną toluen-heksan } 3: 1\end{array}$ & 450 & 2,21 & 3,23 & 0,22 & 0,41 & 0,47 & 0,35 & 0,82 & 394 & 27 & 0,41 \\
\hline
\end{tabular}


Tablica 3. Wyniki badań ekstrahowalnej substancji organicznej wraz ze składem grupowym SARA w próbkach okruchowych czyszczonych z płuczki olejowej mieszaniną toluen-n-heksan $(3: 1 v / v)$

\begin{tabular}{|c|c|c|c|c|c|c|c|c|c|}
\hline \multirow{3}{*}{$\begin{array}{l}\text { Numer } \\
\text { próbki }\end{array}$} & \multirow{3}{*}{$\begin{array}{c}\text { TOC } \\
{[\%]}\end{array}$} & \multirow{3}{*}{$\begin{array}{c}\text { ESO } \\
{[\mathrm{ppm}]}\end{array}$} & \multicolumn{4}{|c|}{ Skład grupowy bituminów [\%] } & \multirow{3}{*}{$\begin{array}{c}\frac{\mathrm{ESO}}{\mathrm{TOC}} \\
{[\mathrm{mg} / \mathrm{g}]}\end{array}$} & \multirow{3}{*}{$\begin{array}{c}\frac{\mathrm{HC}}{\mathrm{TOC}} \\
{[\mathrm{mg} / \mathrm{g}]}\end{array}$} & \multirow{3}{*}{$\frac{\mathrm{HC}}{\mathrm{HZ}}$} \\
\hline & & & \multicolumn{2}{|c|}{ węglowodory HC } & \multicolumn{2}{|c|}{ heterozwiązki HZ } & & & \\
\hline & & & nasycone & aromatyczne & żywice & asfalteny & & & \\
\hline 1 & & & 42,4 & 1,1 & 53,7 & 2,8 & & & 0,8 \\
\hline 2 & 5,32 & 11574 & 5,4 & 6,7 & 81,9 & 6,0 & 218 & 26 & 0,1 \\
\hline 3 & 0,82 & 13180 & 2,2 & 4,7 & 88 & 5,1 & 1607 & 111 & 0,1 \\
\hline
\end{tabular}

TOC - całkowity węgiel organiczny.

ESO - ekstrahowalna substancja organiczna otrzymana w drodze ekstrakcji próbek mieszaniną dichlorometan-metanol (93:7 v/v).

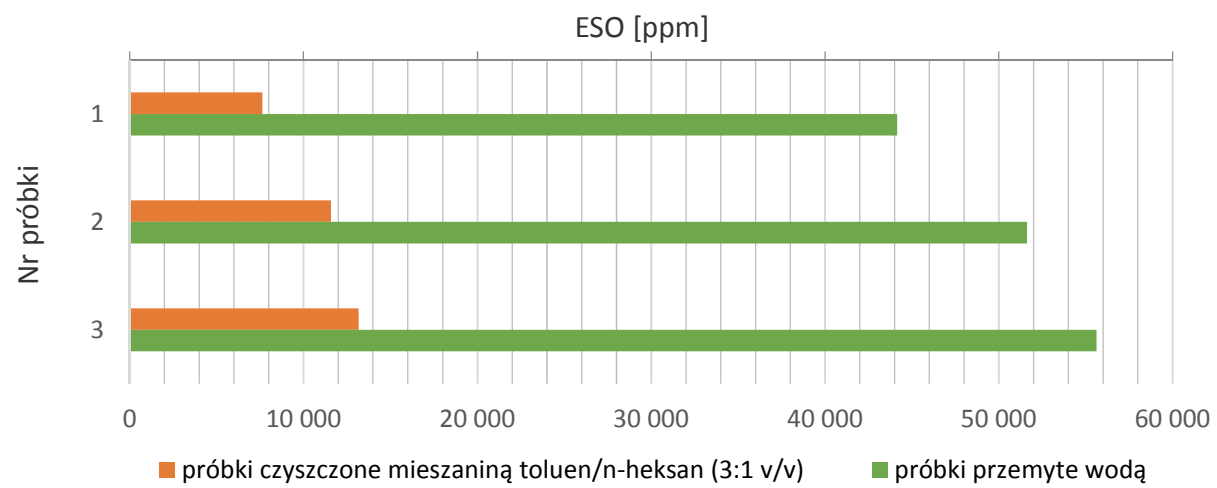

Rys. 1. Zawartość ekstrahowalnej substancji organicznej w próbkach okruchowych zanieczyszczonych płuczką olejową po przemyciu mieszaniną toluen-n-heksan $(3: 1 \mathrm{v} / \mathrm{v})$ oraz po przemyciu wodą

bez użycia rozpuszczalników organicznych. Próbki przed ekstrakcją zostały jedynie przemyte ciepłą wodą i wysuszone na powietrzu. W wyniku ekstrakcji tak przygotowanych próbek uzyskano ponad pięciokrotnie więcej ekstrahowalnej substancji organicznej ESO (od 44148 do 55620 ppm), z przewagą węglowodorów nasyconych nad pozostałymi frakcjami rozdziału grupowego (tablica 4, rysunek 3).

W składzie grupowym zarysowuje się wyraźna przewaga węglowodorów nad heterozwiązkami - stosunek HC/HZ wynosi od 1,10 do 2,30, przy czym zdecydowanie większy udział węglowodorów nasyconych $(39,0 \div 63,8 \% \mathrm{w} / \mathrm{w})$ oraz węglowodorów aromatycznych $(4,5 \div 14,3 \% \mathrm{w} / \mathrm{w})$ (rysunek 2 i 3) obserwuje się w przypadku zastosowania tylko przemy- wania wodą. Zawartość asfaltenów pozostaje bez zmian, natomiast udział żywic jest relatywnie mniejszy, ze względu na wzrost zawartości węglowodorów (metoda bilansowania udziału frakcji do 100\%). Wyniki wskazują, że czyszczenie próbek wodą z dodatkiem detergentu oraz stosowanych środków czyszczących nie gwarantuje usunięcia oleju płuczkowego z próbek okruchowych i może zafałszowywać skład frakcyjny ekstrahowalnej substancji organicznej.

Ogólnie można stwierdzić, że wiercenia z zastosowaniem płuczki olejowej bardzo niekorzystnie wpływają na jakość próbek pobieranych do badań geochemicznych, co w przypadku próbek okruchowych utrudnia, a czasem nawet uniemożliwia klasyczną interpretację uzyskanych wyników badań.

Tablica 4. Wyniki badań ekstrahowalnej substancji organicznej wraz ze składem grupowym SARA w próbkach okruchowych zanieczyszczonych płuczką olejową przemytych wodą (próbki przygotowane bez użycia rozpuszczalników organicznych)

\begin{tabular}{|c|c|c|c|c|c|c|c|c|c|}
\hline \multirow{3}{*}{$\begin{array}{l}\text { Numer } \\
\text { próbki }\end{array}$} & \multirow{3}{*}{$\begin{array}{l}\text { TOC } \\
{[\%]}\end{array}$} & \multirow{3}{*}{$\begin{array}{c}\text { ESO } \\
{[\mathrm{ppm}]}\end{array}$} & \multicolumn{4}{|c|}{ Skład grupowy bituminów [\%] } & \multirow{3}{*}{$\begin{array}{c}\frac{\mathrm{ESO}}{\mathrm{TOC}} \\
{[\mathrm{mg} / \mathrm{g}]}\end{array}$} & \multirow{3}{*}{$\begin{array}{c}\frac{\mathrm{HC}}{\mathrm{TOC}} \\
{[\mathrm{mg} / \mathrm{g}]}\end{array}$} & \multirow{3}{*}{$\frac{\mathrm{HC}}{\mathrm{HZ}}$} \\
\hline & & & \multicolumn{2}{|c|}{ węglowodory HC } & \multicolumn{2}{|c|}{ heterozwiązki HZ } & & & \\
\hline & & & nasycone & aromatyczne & żywice & asfalteny & & & \\
\hline 1 & & & 63,8 & 6,2 & 25,3 & 4,7 & 856 & 599 & 2,3 \\
\hline 2 & 6,71 & 51622 & 39,0 & 14,3 & 40,9 & 5,8 & 769 & 410 & 1,1 \\
\hline 3 & 1,90 & 55620 & 48,8 & 5,4 & 38,6 & 7,2 & 2927 & 1587 & 1,2 \\
\hline
\end{tabular}




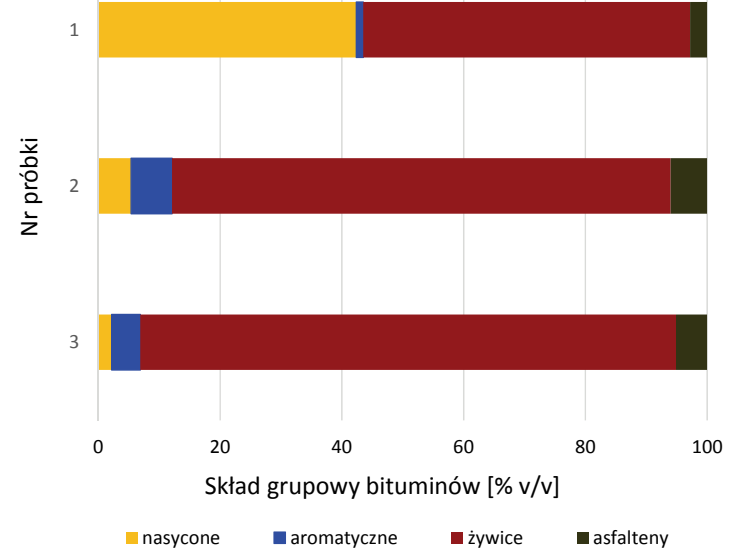

Rys. 2. Skład grupowy (SARA) ekstrahowalnej substancji organicznej w próbkach okruchowych czyszczonych z płuczki olejowej mieszaniną toluen-n-heksan $(3: 1)$

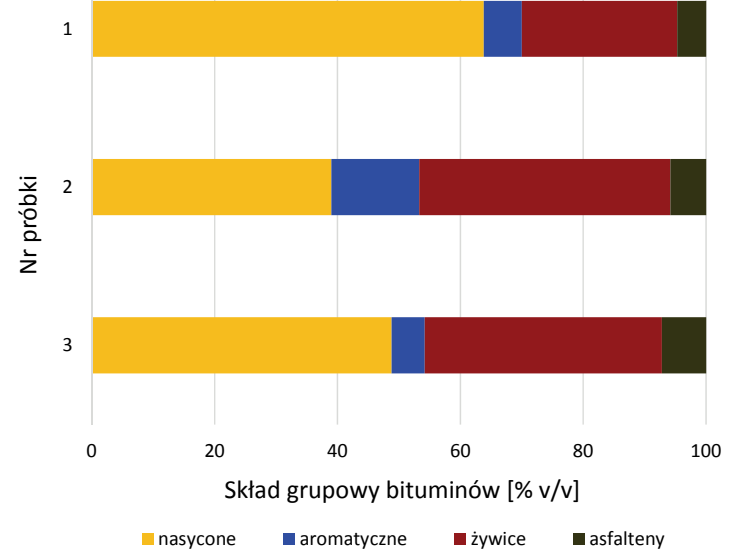

Rys. 3. Skład grupowy (SARA) ekstrahowalnej substancji organicznej w próbkach okruchowych zanieczyszczonych płuczką olejową przemytych wodą (próbki przygotowane bez użycia rozpuszczalników organicznych)

\section{Ocena stopnia zanieczyszczenia próbek rdzeniowych i okruchowych składnikami olejowymi płuczki}

Aby ocenić, w jakim stopniu składniki płuczki olejowej mogą penetrować próbki okruchowe lub rdzeniowe, przeprowadzono testy na próbkach zróżnicowanych litologicznie i wykazujących zróżnicowane parametry przepuszczalności.

Testy takie miały na celu pozyskanie informacji na temat wielkości odchyleń w poszczególnych parametrach geochemicznych w zależności od typu przepuszczalności i litologii badanych próbek. Taka informacja będzie bardzo przydatna w wypracowaniu podejścia interpretacyjnego $\mathrm{w}$ analizie wyników z badań rdzeni i prób okruchowych, jeżeli próbki te uzyskuje się z wierceń, gdzie była stosowana płuczka olejowa.

Wyniki otrzymane w testach porównawczych zestawiono na rysunkach 4-6. Tak jak oczekiwano, największy wpływ zaznacza się w wartościach parametru $S_{1}$ (rysunek 4a), który reprezentuje wolne węglowodory, a więc dokładnie zakres lekkich węglowodorów ulegających odparowaniu w temperaturze $100 \div 300^{\circ} \mathrm{C}$. Takie lekkie węglowodory są obecne

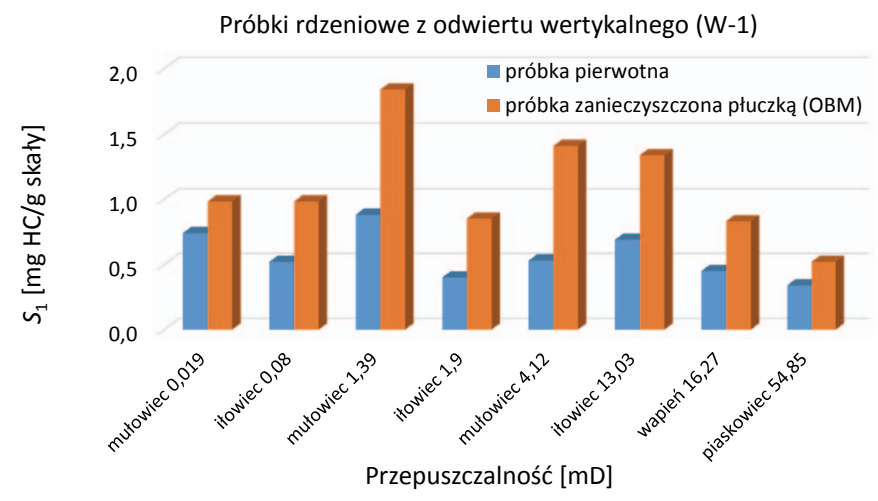

Rys. 4a. Zmiana wartości parametru $S_{1}$ dla próbek rdzeniowych zanieczyszczonych płuczką olejową OBM (oil-based mud) w składnikach oleju dodawanego do bazy płuczkowej. Najwyższy procentowy wzrost parametru $S_{1}$ (o $62 \%$ ) po skażeniu płuczką uzyskano w przypadku próbki iłowca o przepuszczalności 4,12 $\mathrm{mD}$ (rysunek 4b). Dla pozostałych próbek przyrost parametru $S_{1}$ - bez względu na litologię i przepuszczalność - jest w zakresie $45 \div 52 \%$.

Zmiana wartości parametru $S_{2}$, reprezentującego potencjał generacyjny, nie jest już tak duża, co ilustrują rysunki 5a i 5 b. Jest to o tyle oczywiste, że węglowodory rozkładające się w wyższej temperaturze (zakres piku $S_{2}$ to temp. rozkładu $300 \div 650^{\circ} \mathrm{C}$ ) nie są składnikami oleju. Wzrost tego parametru jest niewielki i pozostaje w zakresie $4 \div 15 \%$.

Podobny trend daje się zauważyć podczas analizy parametru TOC, który jest ściśle związany z wcześniej omawianymi parametrami $S_{1}$ i $S_{2}$ (rysunki 6a i 6b).

Analogiczne testy przeprowadzono na próbkach okruchowych łupków menilitowych, które charakteryzują się

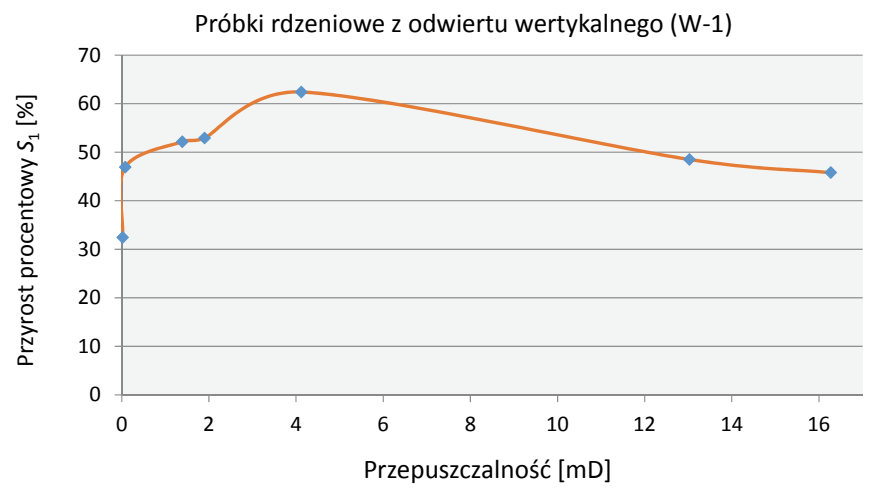

Rys. 4b. Wykres ilustrujący procentową zmianę parametru $S_{1}$ po skażeniu próbki rdzeniowej płuczką olejową 


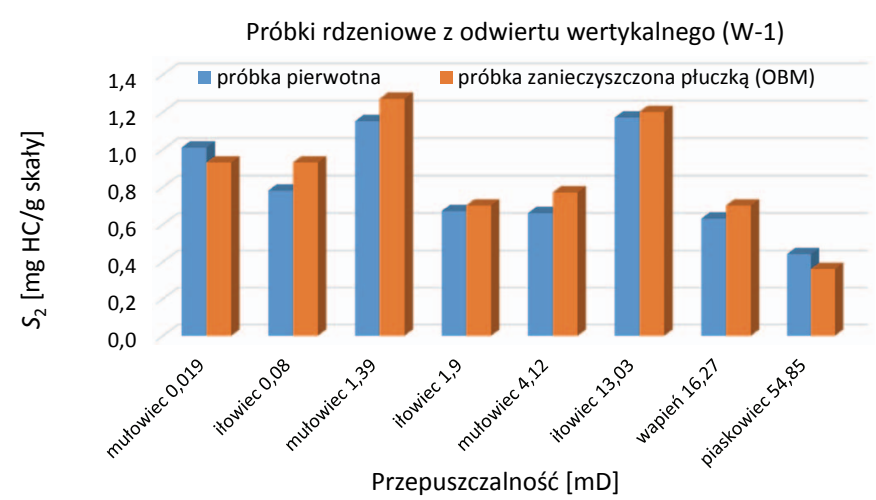

Rys. 5a. Zmiana wartości parametru $S_{2}$ dla próbek rdzeniowych zanieczyszczonych płuczką olejową OBM (oil-based mud)

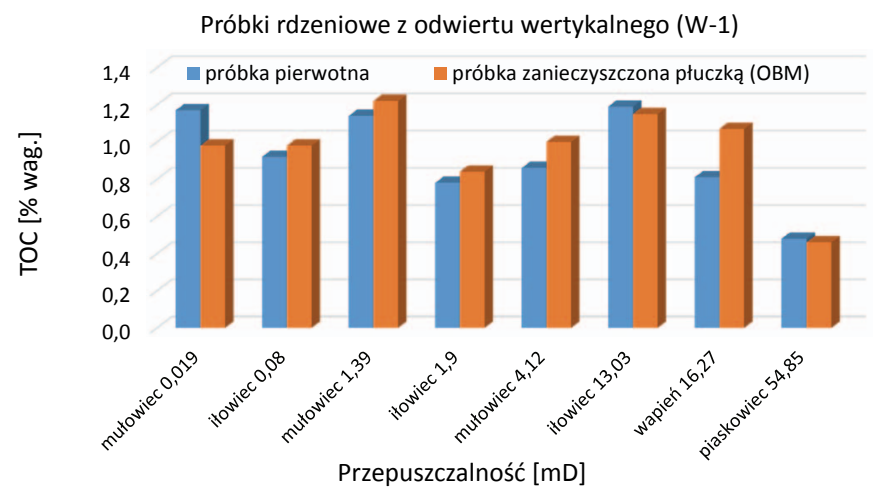

Rys. 6a. Zmiana wartości parametru TOC dla próbek rdzeniowych zanieczyszczonych płuczką olejową OBM (oil-based mud)

zwykle wysoką zawartością substancji organicznej, zarówno bituminów, jak i kerogenu ropotwórczego. W przypadku próbek okruchowych penetracja oleju jest bardzo zauważalna i wpływa na zwielokrotnienie wartości parametrów $S_{1}, S_{2}$ i TOC (rysunki 7-9). Wzrost wartości tych parametrów wiąże się prawdopodobnie z typem występujących w próbkach węglowodorów, które są łatwo rozpuszczalne w składnikach oleju stosowanego do sporządzenia płuczki.

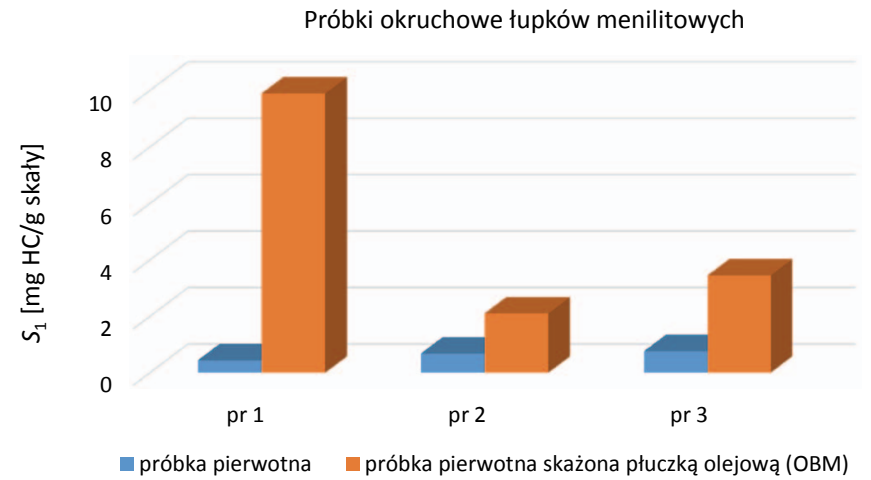

Rys. 7. Zmiana wartości parametru $S_{1}$ dla próbek łupków menilitowych zanieczyszczonych (skażonych) płuczką olejową (OBM)

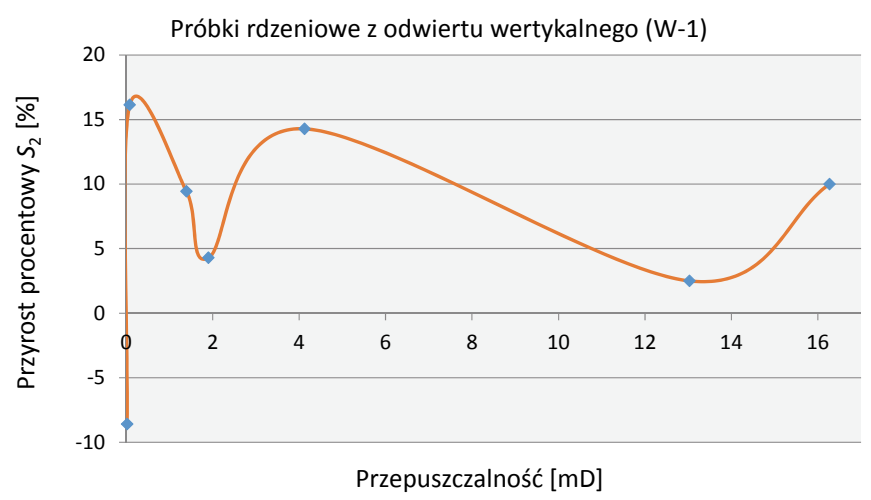

Rys. 5b. Wykres ilustrujący procentową zmianę parametru $S_{2}$ po zanieczyszczeniu próbek rdzeniowych płuczką olejową

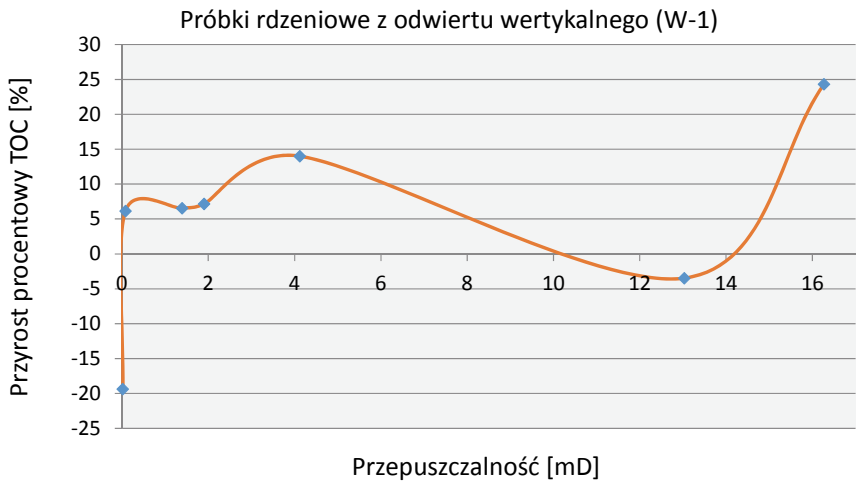

Rys. 6b. Wykres ilustrujący procentową zmianę parametru TOC po zanieczyszczeniu próbek rdzeniowych płuczką olejową

Stąd podczas testów zaobserwowano anomalne przypadki zmian relatywnych wartości TOC, $S_{2}$ i $S_{1}$, zmieniających układ w stosunku do próbek pierwotnych. Generalnie można stwierdzić na bazie wszystkich obserwacji po testach zanieczyszczenia płuczką, że największy wpływ oleju syntetycznego otrzymano dla wartości parametru $S_{1}$, bez względu na rodzaj próbek, większy w przypadku próbek okruchowych. W przypadku próbek okruchowych z formacji

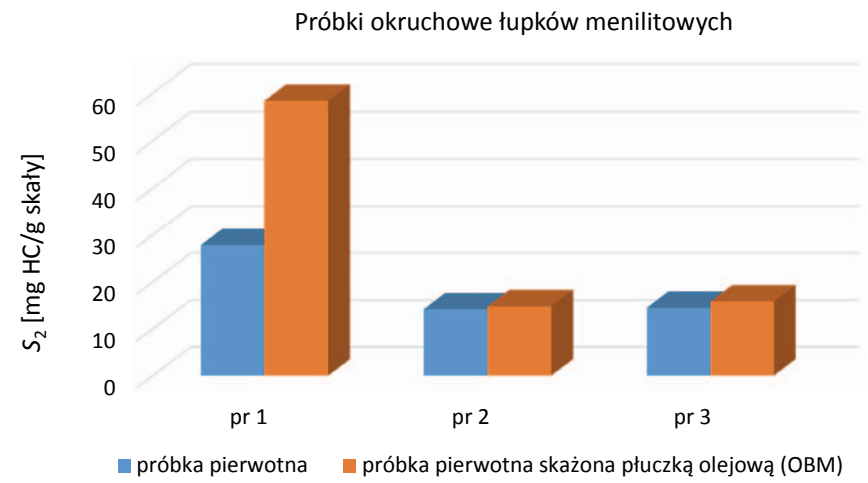

Rys. 8. Zmiana wartości parametru $S_{2}$ dla próbek łupków menilitowych zanieczyszczonych (skażonych) płuczką olejową (OBM) 


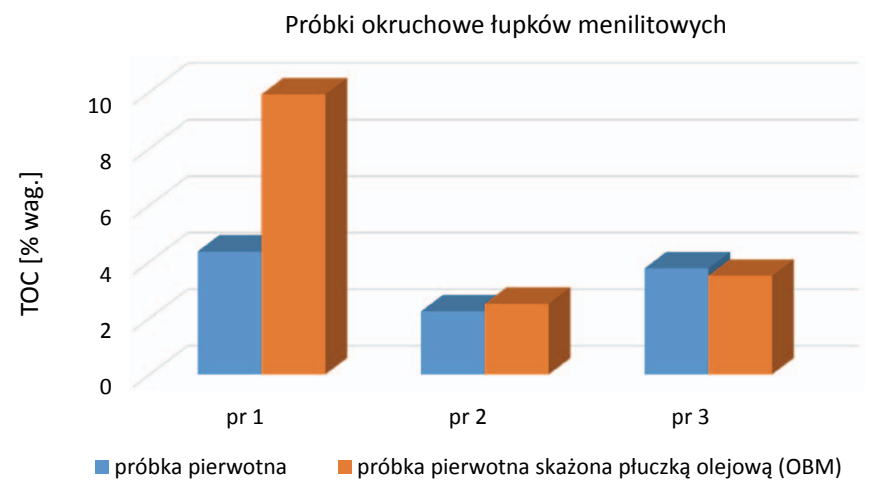

Rys. 9. Zmiana wartości parametru TOC dla próbek łupków menilitowych zanieczyszczonych (skażonych) płuczką olejową (OBM) łupkowych, zwłaszcza z otworów horyzontalnych, uzyskiwano stosunkowo wysokie wskazania zawartości wolnych węglowodorów w stosunku do analogicznych wskazań w otworach wertykalnych, gdzie były pobierane próbki rdzeniowe i stosowano płuczkę bez dodatków olejowych.

\section{Podsumowanie}

Przetestowanie różnych rozpuszczalników z wykorzystaniem rzeczywistych próbek pozwoliło na wybranie optymalnych warunków oczyszczania próbek do badań geochemicznych. Najlepsze efekty czyszczące uzyskano przy zastosowaniu alkoholu izopropylowego, jednak nie oznacza to wcale, że usunięto jedynie olejowy składnik płuczki, bez naruszenia substancji organicznej próbek.

W pracy przetestowano skuteczność różnych mieszanin i rozpuszczalników w oczyszczaniu próbek okruchowych i rdzeniowych zanieczyszczonych składnikami płuczki olejowej. Przeprowadzone testy wykazały, że żadna z użytych czyszczących substancji nie spełniła pokładanych nadziei, tzn. nie usunęła olejowego składnika płuczki bez naruszenia substancji organicznej próbki. W przeprowadzonych eksperymentach śledzono efekt czyszczenia z zastosowaniem różnych czynników czyszczących. W żadnym przypadku nie uzyskano w $100 \%$ satysfakcjonującego efektu w postaci selektywnego wymycia niepożądanych zanieczyszczeń.

Trudno określić, w jakim stopniu czynnik czyszczący usuwa olej mineralny, a w jakim węglowodory zawarte w skale. Przykład użycia mieszaniny toluen-n-heksan wraz ze wszystkimi obserwacjami testów skłaniają do opinii, że nie ma substancji, która by w sposób selektywny usuwała niepożądany składnik płuczki, zwłaszcza z próbek okruchowych.

Pomimo braku wyboru jednego środka czyszczącego udato się zminimalizować o 50\% efekt zanieczyszczenia w drodze płukania alkoholem izopropylowym.

W drugim etapie pracy przeanalizowano wpływ składników płuczki olejowej na uzyskiwane parametry z badań geochemicznych próbek okruchowych oraz rdzeniowych. $\mathrm{Z}$ analizy wynika, że:

- największy wpływ zaznacza się w wartościach parametru $S_{1}$ (Rock Eval), który reprezentuje wolne węglowodory, a więc dokładnie zakres lekkich węglowodorów ule- gających odparowaniu w temperaturze $100 \div 300^{\circ} \mathrm{C}$. Takie lekkie węglowodory są obecne w składnikach oleju dodawanego do bazy płuczkowej. Najwyższy procentowy wzrost parametru $S_{1}$ (o $62 \%$ ) po zanieczyszczeniu próbki rdzeniowej płuczką uzyskano w przypadku próbki iłowca o przepuszczalności $4,12 \mathrm{mD}$. Dla pozostałych próbek przyrost parametru $S_{1}$, bez względu na litologię i przepuszczalność, jest w zakresie $45 \div 52 \%$;

- zmiana wartości parametru $S_{2}$, reprezentującego potencjał generacyjny, nie jest już tak duża, co jest o tyle oczywiste, że węglowodory pirolitycznie uwalniające się w wyższej temperaturze (zakres piku $S_{2}$ to temp. rozkładu $300 \div 650^{\circ} \mathrm{C}$ ) nie są składnikami oleju. Wzrost tego parametru jest niewielki i pozostaje w zakresie $4 \div 15 \%$;

- podobny trend daje się zauważyć podczas analizy parametru TOC, który jest ściśle związany z parametrami $S_{1}$ i $S_{2}$;

- analogiczne testy przeprowadzone na próbkach okruchowych łupków menilitowych, które charakteryzują się zwykle wysoką zawartością substancji organicznej, zarówno bituminów, jak i kerogenu ropotwórczego, wykazały znacznie głębszą penetrację oleju, co objawia się zwielokrotnieniem wartości parametrów $S_{1}, S_{2}$;

- wzrost wartości parametrów $S_{1}$ i $S_{2}$ w przypadku bogatych $\mathrm{w}$ organikę łupków menilitowych jest prawdopodobnie związany z rodzajem występujących w nich węglowodorów, które są łatwo rozpuszczalne w składnikach oleju stosowanego do bazy płuczkowej.

Generalnie po testach zanieczyszczenia płuczką olejową można stwierdzić, że największy wpływ oleju bazowego otrzymano dla wartości parametru $S_{1}$, bez względu na rodzaj próbek, większy w przypadku próbek okruchowych. Przed przystąpieniem do prac laboratoryjnych należy zatem uzyskać informację co do warunków wiercenia otworu i stosowanych płynów technologicznych. 
Prosimy cytować jako: Nafta-Gaz 2017, nr 7, s. 465-472, DOI: 10.18668/NG.2017.07.03

Artykuł nadesłano do Redakcji 14.12.2016 r. Zatwierdzono do druku 24.05.2017 r.

Artykuł powstał na podstawie pracy statutowej pt. Dobór optymalnej metody oczyszczania rdzeni i prób okruchowych z płuczki olejowej na etapie przygotowania próbek do badań geochemicznych - praca INiG - PIB na zlecenie MNiSW; nr zlecenia: 106/ SG/2016, nr archiwalny: DK-4100-106/16.

\section{Literatura}

[1] Błaż S.: Badania laboratoryjne nad opracowaniem składu ptuczki inwersyjnej. Nafta-Gaz 2015, nr 3, s. 149-158.

[2] Błaż S.: Badania laboratoryjne nad opracowaniem składu płuczki wiertniczej do przewiercania formacji tupkowych. Nafta-Gaz 2013, nr 2, s. 123-133.

[3] Intertek Geotech, strona internetowa, http://www.geotechnical-services.com.au (dostęp: październik 2016).

[4] Karta charakterystyki Sintanu.

[5] Morrell G.R., Mc Alpine K.D.: Oil-based mud and its impact on geochemistry, microfossils and organic material. Geological Survey of Canada (PERD) 1995, Open File no 3008.

[6] Ohm S.E., Karlsen D.A., Backer-Owe K., Pedersen J.H., Beeley H.S.: A drilling mud additive influencing the geochemical interpretations of hydrocarbon shows. Petroleum Geoscience 2007, vol. 13, s. 369-376.

Mgr Marek ZAPAŁA

Starszy specjalista inżynieryjno-techniczny w Zakładzie Geologii i Geochemii.

Instytut Nafty i Gazu - Państwowy Instytut Badawczy

ul. Lubicz 25 A

31-503 Kraków

E-mail:marek.zapala@inig.pl

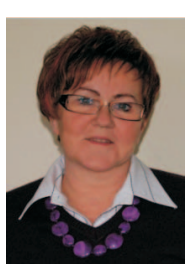

Prof. nzw. dr hab. inż. Irena MATYASIK

Adiunkt, kierownik Laboratorium Nafty i Gazu

w Zakładzie Geologii i Geochemii.

Instytut Nafty i Gazu - Państwowy Instytut Badawczy

ul. Lubicz 25 A

31-503 Kraków

E-mail: irena.matyasik@inig.pl
[7] Olufemi A. Adekomaya, Olalekan Olafuyi: An experimental study of the effect of contaminants on the flow properties of oil based drilling mud. Petroleum \& Coal 2011, vol. 53, nr 4, s. 315-319.

[8] Perry M.L., Griffin J.M.: Chemical Treatment of Cuttings Drilled With Oil-Based Mud Employing a Laboratory Simulated Soil Washing Procedure. Paper SPE 66593 presented at the SPE/EPA/DOE Exploration and Production Environmental Conference, San Antonio, Texas 26-28.02.2001.

[9] Reddy B.R., Whitfill D., Robb I., Dealy T.: Chemical Method for Cleanup of Produced Oil-Coated Solids from Oil Well Operations. Proceedings of the International Petroleum Environmental Conference (10 ${ }^{\text {th }}$ IPEC), Houston, Texas, 11-14.11.2003.

[10] Ross S., Biersteker M.: Method for cleaning oil from drill cuttings. Patent US 20120090898 A1, 2012.

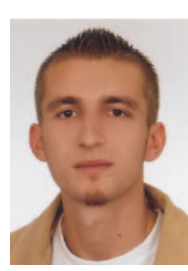

Mgr inż. Wojciech BIELEŃ

Starszy specjalista badawczo-techniczny w Zakładzie Geologii i Geochemii.

Instytut Nafty i Gazu - Państwowy Instytut Badawczy

ul. Lubicz 25 A

31-503 Kraków

E-mail:wojciech.bielen@inig.pl

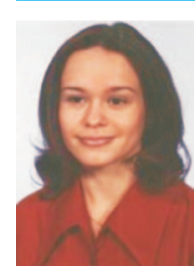

Mgr Małgorzata KANIA

Asystent w Zakładzie Geologii i Geochemii. Instytut Nafty i Gazu - Państwowy Instytut Badawczy ul. Lubicz 25 A

31-503 Kraków

E-mail: kaniam@inig.pl 